\title{
Regulation and Supervision of Islamic Banks
}


Regulation and Supervision of Islamic Banks

Alejandro López Mejía, Suliman Aljabrin, Rachid Awad, Mohamed Norat, and Inwon Song 


\title{
IMF Working Paper
}

Monetary and Capital Markets Department

\section{Regulation and Supervision of Islamic Banks}

\section{Prepared by Alejandro López Mejía, Suliman Aljabrin, Rachid Awad, Mohamed Norat, and Inwon Song ${ }^{1}$}

Authorized for distribution by Michaela Erbenova

December 2014

\section{This Working Paper should not be reported as representing the views of the IMF.}

The views expressed in this Working Paper are those of the author(s) and do not necessarily represent those of the IMF or IMF policy. Working Papers describe research in progress by the author(s) and are published to elicit comments and to further debate.

\begin{abstract}
This paper aims at developing a better understanding of Islamic banking (IB) and providing policy recommendations to enhance the supervision of Islamic banks (IBs). It points out and discusses similarities and differences of IBs with conventional banks (CBs) and reviews whether the IBs are more stable than CBs. Given the risks faced by IBs, the paper concludes that they need a legal, corporate and regulatory framework as much as CB does. The paper also argues that it is important to ensure operational independence of the supervisory agency, which has to be supported by adequate resources, a sound legal framework, a well designed governance structure, and robust accountability practices.
\end{abstract}

JEL Classification Numbers: G18, G21, P51

Keywords: Islamic banks, conventional banks, regulatory framework, banking supervision

Author's E-Mail Address: alopezmejia@imf.org; saljabrin@imf.org; rawad@imf.org; mnorat@,imf.org; isong@,imf.org

\footnotetext{
${ }^{1}$ This working paper benefitted from comments by Rima Turk (IMF-Middle East Center for Economics and Finance, Kuwait), participants in seminars organized by the Interdepartmental Working Group on Islamic Finance at the IMF, and discussions with Professor Simon Archer and Peter Casey (Islamic Financial Services Board), Professor Mahmoud El-Gamal, and Ahmad El Radi (IMF- Middle East Regional Technical Assistance Center, Lebanon).
} 


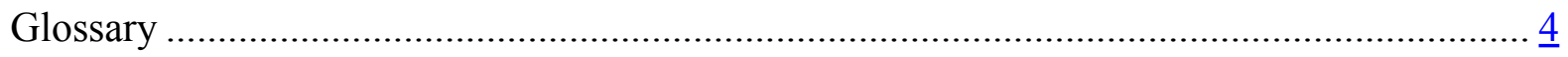

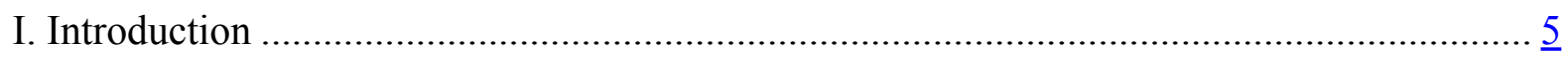

II. Characteristics of Islamic Banking …………….......................................................

III. Are Islamic Banks more Stable than Conventional banks? ................................................ $\underline{9}$

IV. The Legal, Corporate And Regulatory Frameworks In Islamic Banking......................... $\underline{13}$

A. The Legal Framework .................................................................................... 13

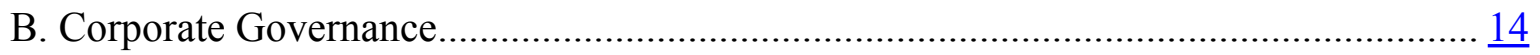

C. The Regulatory Framework …………………………………………………. 15

V. The Supervision of Islamic Banking in Practice …………………………………..... 20

VI. Conclusions and Main Policy Recommendations ……................................................ 22

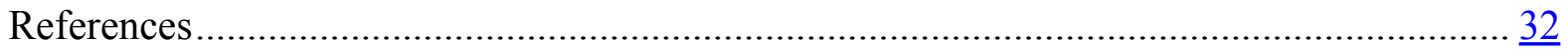

Table

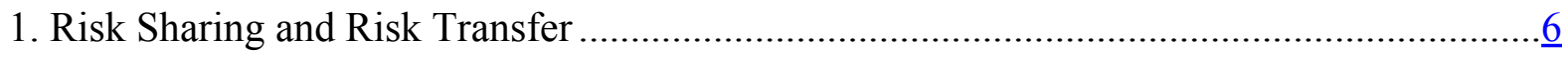

Figure

1. The Growing Importance of Islamic Banks ....................................................................

Annexes

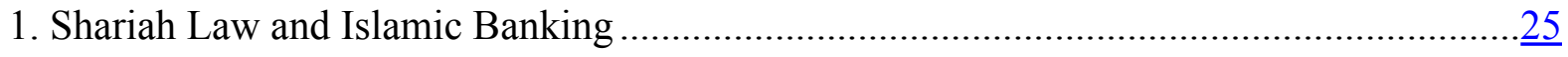

2. Definition of key Shariah-compliant Contracts ……………….....................................

3. Islamic Window vs. Fully-fledged Islamic Bank ………..............................................

4. Capital Adequacy in Islamic Banking ………………............................................... 


\section{GLOSSARY}

$\begin{array}{ll}\text { AAOIFI } & \text { Accounting and Auditing Organization for Islamic Financial Institutions } \\ \text { BCBS } & \text { Basel Committee on Banking Supervision } \\ \text { BCP } & \text { Basel Core Principles for Effective Bank Supervision } \\ \text { CAMELS } & \text { Capital-Asset-Management-Earnings-Liquidity-Sensitivity } \\ \text { CAR } & \text { Capital adequacy ratio } \\ \text { CB } & \text { Conventional Banking } \\ \text { FSI } & \text { Financial soundness indicators } \\ \text { HQLA } & \text { High quality liquid assets } \\ \text { IB } & \text { Islamic Banking } \\ \text { IFRS } & \text { International Financial Reporting Standards } \\ \text { IFSB } & \text { Islamic Financial Services Board } \\ \text { IRR } & \text { Investment risk reserves } \\ \text { LCR } & \text { Liquidity coverage ratio } \\ \text { NFSR } & \text { Net stable funding ratio } \\ \text { PER } & \text { Profit equalization reserves } \\ \text { PLS } & \text { Profit and loss sharing } \\ \text { PSIA } & \text { Profit sharing investment account } \\ \text { RIA } & \text { Restricted investment account } \\ \text { SSB } & \text { Shariah Supervisory Board } \\ \text { URIA } & \text { Unrestricted profit sharing account }\end{array}$




\section{INTRODUCTION}

Islamic banking (IB) has grown rapidly across several regions and is systemically important in key economies (Figure 1). ${ }^{2}$ Indeed, the IB sector has expanded by over 15 percent per annum during the last five years and its assets are estimated to exceed US\$1.5 trillion. Moreover, while IB is particularly large in many Muslim countries (and systemic in many countries including Iran, Sudan, Saudi Arabia, Kuwait, and Qatar), there is an increasing interest in Islamic finance in non-Muslim countries.

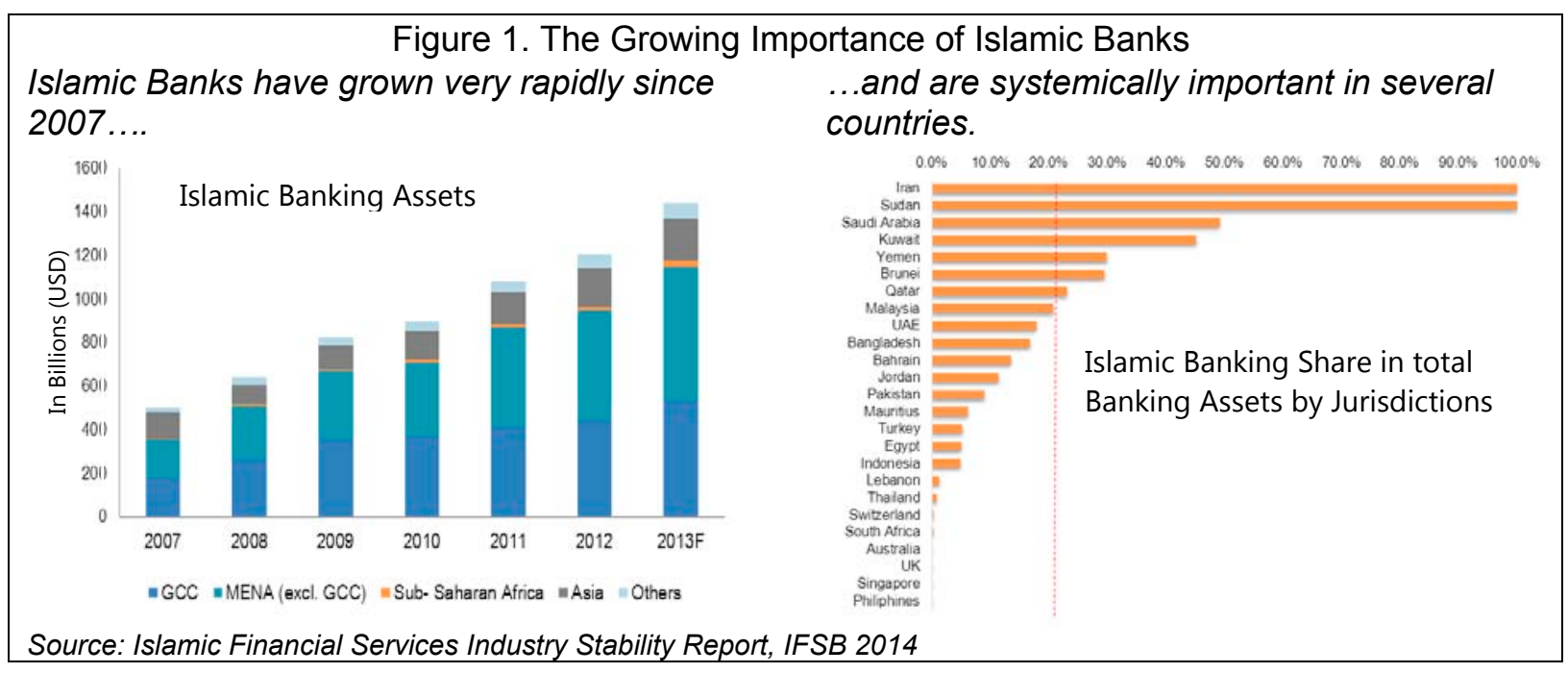

Despite this expansion, IB remains unchartered territory for many practitioners and policy makers. That said, there is already a significant literature that discusses key characteristics of IB and their implications for regulation and supervision. Based on a brief review of this literature, this note aims at developing a better understanding of IB and providing policy recommendations to enhance further the supervision and regulation of Islamic banks (IBs). The note is divided into six sections. Section II reviews the key characteristics of IB banking. Section III discusses whether IBs are more stable than conventional banks (CBs). Section IV discusses the legal, corporate and regulatory frameworks of IBs; whereas section V reviews supervisory issues. Section VI concludes.

\section{ChaRACTERISTICS OF ISLAMIC BANKING}

Islamic and conventional banks share many similarities. They are profit maximizing entities that are crucial for the efficient allocation of resources and consequently reduce information asymmetries, help reduce transaction costs and facilitate diversification for small savers and investors. As financial intermediaries, these institutions provide services such as: asset

\footnotetext{
${ }^{2}$ According to the Islamic Financial Stability Report (2014), an Islamic financial sector is considered systemically important in a country when total Islamic banking assets comprise more than 20 percent of total domestic banking sector assets, or at least 5 percent of the global portfolio of Islamic banking assets.
} 
transformation, a payment system, custodial services, and risk management (Van Greuning and Iqbal, 2008).

In theory, however, Islamic and conventional banking differ in important ways. ${ }^{3}$ While conventional banks' (CBs) intermediation is largely debt-based and allows for risk transfer, IBs intermediation is asset-based and centers on risk sharing (Table 1). This largely reflects that IB is based on compliance with Shariah law, which generally prohibits (among others) the sale and purchase of debt contracts in order to receive an interest gain, profit taking without real economic activity and asset transfer, and legal uncertainty surrounding the contractual claims (Annex 1). Accordingly, IB could potentially play a key role in gearing finance in the countries they operate towards a social common goal tied to supporting the real economy and possibly reducing the incentives to financial engineering associated with opaque and complex instruments. However, this would require significant enhancements in the current legal, accounting, governance, regulatory and supervisory frameworks (sections IV and V).

\section{Table 1. Risk Sharing and Risk Transfer}

\begin{tabular}{l} 
IBs Risk Sharing \\
\hline $\begin{array}{l}\text { Sources of funds: Investors (profit sharing } \\
\text { investment account (PSIA holders) share the } \\
\text { risk and return with IBs. The return on PSIA } \\
\text { is not guaranteed and depends on the } \\
\text { bank's performance. }\end{array}$
\end{tabular}

Uses of funds: IBs share the risk in Mudharabah and Musharakah contracts and conduct sales contracts in most other contracts (Annex 2 provides a definition of key Shariah-compliant contracts).
CBs Risk Transfer

Sources of Funds: Depositors transfer the risk to the $\mathrm{CB}$, which guarantees a prespecified return.

Source: Hasan and Dridi, 2010.

In practice, however, the differences between IBs and CBs are relatively small. Reasons include: i) many conventional banking products can be redrafted as Shariah-compliant products; ii) IBs differ in the level of risk sharing. Indeed, on the funding side, while profit sharing investment accounts (PSIAs) still constitute an important source of funds, IBs also accept savings and demand deposits (which do not have the risk-sharing features of PSIAs) and, on the asset side, risk sharing contracts have become the exception rather than the rule, with most financing taking the form of Murabahah contracts (cost plus financing) or

\footnotetext{
${ }^{3}$ IB activities encompass mutual and equity fund like activities, possibly requiring a more cross-sectional approach to regulation and supervision (rather than a strictly banking approach). Therefore, the development of IB banking regulations, standards and core principles need to be broader in scope.
} 
installment sales (Hasan and Dridi, 2010). As a result, as is the case in CBs, credit risk has become a key risk faced by IBs. This is consistent with empirical findings indicating that: i) there are few significant differences in the business models of IBs and CBs (Beck, Demirgüç-Kunt and Merrouche, 2013); ii) a small portion of IBs financing is based on profit loss sharing, and (iii) Islamic accounts are not very different from conventional deposits as the rate of return on PSIAs is closely pegged to conventional deposits (Chong and Liu, 2009, and Khan, 2010).

Given the need to comply with Shariah law, IBs are prohibited from undertaking transactions based on fixed or predetermined rate of interest. This gives rise to the usage of contracts, whereby interest rates are replaced by: i) a rate of return that is determined ex post on the basis of actual profits accrued from profit and loss sharing (PLS) arrangements for investments in the real sector, ii) a mark-up determined based on a benchmark rate of return (such as LIBOR) for the purchase and resale of goods and services and iii) the provision of services for fees. Contract types in IB can be broadly divided into transactional and intermediation contracts (El-Hawary, Grais and Iqbal, 2004). ${ }^{4}$

- $\quad$ Transactional contracts govern real transactions, such as trade and the financing of economic activities. This can take the form of sale (bai), exchange (sarf), partnership (shirkah) and right-to-use (ijarah). The core transactional contracts are based on: i) commodity trade contracts (e.g., murabahah and salam) that are broadly similar to asset-backed securities; ii) a system that promotes equity participation (musharakah); and iii) other collateralized securities such as those originating from leasing (ijarah).

- Intermediation contracts facilitate an efficient and transparent execution of transactional contracts. These help: i) develop a partnership between an economic agent with capital and an agent with expertise in deploying capital into real activities with an agreement to share profits (mudharabah), and ii) provide several financial services such as custodial services, brokerage, consulting, guarantees and insurance.

In theory, there are two models of banking operation in an Islamic framework (Errico and Farrahbaksh, 1998):

- $\quad$ The two-tier mudharabah model. In this model, banks' assets and liabilities are fully integrated and, thus minimize the risk for active asset/liability management. On the liability side, the investor (provider of funds or investment account holder) enters into a mudharabah contract with the bank to share in the profits earned by the bank. These funds are placed in an investment account, where the capital is not guaranteed, though there are also deposits that yield no return and are guaranteed on capital value. On the

\footnotetext{
${ }^{4}$ This paper excludes any discussion of social welfare contracts including takaful, re-takaful (mutual protection), qard-e-Hasan (a gratuitous loan), use of waqf (trust), zakaat (charity) and awqaf(endowments).
} 
asset side, the bank enters into a mudharabah contract with entrepreneurs who are seeking funds and agree to share profits according to certain percentage stipulated in the contract. This model does not mandate reserve requirements on either investment or demand deposits.

- $\quad$ The two-window model. In this model, banks' liabilities are divided into two windows based on the choice made by depositors. The first window is for demand deposits and used for safekeeping and the second is for investment deposits and used to finance risk-bearing investments. This model requires banks to hold a 100 percent reserve on demand deposits that are guaranteed by the bank and a zero percent reserve on investment accounts.

In practice, IB balance sheets differ from these two models (El-Hawary, Grais and Iqbal, 2004). First, on the asset side, there is a clear preference for asset-backed securities (based on trade and commodity finance) and leasing as it is considered to have lower risks and less uncertain returns than mudharabah and musharakah (though this adds to banks' exposure to credit and operational risks). Second, there are no barriers in the deployment of assets between those funded by demand deposits, investment accounts, and equity, posing a challenge to regulators as different stakeholders in the bank need to be regulated under different principles. Third, although investment accounts are supposed to be operating on profit and loss sharing principles, losses in the asset side are absorbed by equity holders, raising a question on the degree of transparency and disclosure. ${ }^{5}$ Fourth, holders of investment accounts are not granted any participation in the bank governance and monitoring process, potentially creating a divergence of interests with shareholders that needs to be recognized in the bank's governance structure.

There are three broad stages through which a country may possibly pass through as IB develops (Solé, 2007). ${ }^{6}$ In a first stage selected Islamic products are offered. This can be done via two channels: i) opening an "Islamic window," that is, a window within a conventional bank via which customers can conduct business using only Shariah compatible instruments and which can be segregated as the activities of the IB expands (Annex 3 presents pros and cons of Islamic windows); ii) offering products (e.g., sovereign and corporate sukuks) specifically designed to attract Shariah-compliant investors. A second stage is where fullfledged IBs are allowed to operate once the Islamic window has gathered a sizable customer base (either by establishing an Islamic subsidiary or converting into a full-fledged Islamic

\footnotetext{
${ }^{5}$ This is not an issue if the losses from investments are due to negligence and misconduct and in markets where Islamic banks maintain investment risk reserves (IRR) as these reserves will absorb losses on the asset side. If these reserves are insufficient, the losses will shared between the investment account holders and the bank. About 37 percent of countries with IBs have allowed IRR (Song and Oosthuizen, 2014).

${ }^{6}$ However, some countries (e.g., Oman) have started Islamic finance operations without necessarily following this sequential approach.
} 
bank). The third stage is where non-bank Islamic institutions expand the range of Islamic financial products available (among others, these include insurance products (takaful), investment funds and sukuks, and derivative instruments).

\section{Are IsLAmic Banks More Stable than CONVENTIONAL BANKS?}

While in theory IBs are less susceptible to instability than conventional banks, in practice they are just as exposed to risks as CBs. In theory, the comparative advantage of IBs is its risk sharing feature (i.e., banks participate in the risks of their counterparties and investment depositors share the risk of the banking business). In practice, this advantage is neutralized as IBs end up paying to investment accounts holders competitive "market" returns regardless of their performance. Moreover, IBs shift away from profit and loss sharing (PLS) activities and their asset portfolios become largely composed of short-term, low profit and trade related transactions (El-Hawary, Grais and Iqbal, 2004).

The nature of some risks faced by IBs and CBs is different. ${ }^{7}$ Risks that are unique to IBs arise directly from the specific characteristics of Islamic contracts (including the nature of risksharing). Risks specific to IBs include: ${ }^{8}$

- Shariah compliance risk: Inadequate compliance with Shariah law could weaken consumer protection as a result of fraudulent activities and misinterpretations of the fundamental Shariah rules. If depositors lose confidence in IBs'Shariah compliance, a bank could face financial problems, starting possibly with liquidity and developing ultimately into solvency issues (which could become systemic if the IB is sufficiently large and connected).

- $\quad$ Equity investment risk: It arises from entering into a partnership for the purpose of undertaking or participating in a business activity and in which the provider of funds shares the business risks.

- $\quad$ Rate of return risk: It arises when an increase in benchmark rates results in expectations of higher rates of return on investment accounts, even though the actual rate cannot be exactly determined until the end of the investment holding period.

- $\quad$ Displaced commercial risk: This risk is a consequence of the rate of return risk. It arises when an Islamic bank is under pressure of paying its investment account holders (IAHs) a rate of return higher than what would be payable under the "actual"

\footnotetext{
${ }^{7}$ El-Hawary, Grais and Iqbal (2004) present a comprehensive discussion on the risks faced by IBs.

${ }^{8}$ Some of the literature on Islamic banking notes that withdrawal risk is also a specific risk to IBs. However, $\mathrm{CB}$ also face this risk, which arises from the competitive pressures an IB faces from existing Islamic or conventional counterparts. It is the risk of deposit withdrawals as a result of the lower rate they would receive compared to what its competitors pay.
} 
terms of the investment contract in order to induce its IAHs not to withdraw their funds to invest them elsewhere.

In order to minimize these risks, some markets where IBs are present maintain reserves, including:

- $\quad$ Profit equalization reserves (PER): It is an amount set aside from the investment profits before allocation between the shareholders and the unrestricted investment account holders and the calculation of the bank's share of profits. It is used to reduce the variability of profit payouts on investment deposits to offer returns that are aligned to a market rate of return without the need for the bank to forgo any of its shares when investment returns decline. ${ }^{9}$

- Investment risk reserves (IRR): It is the amount appropriated by the institution offering Islamic financial services out of the income of investment account holders after deducting the share of the bank. It can be used to redistribute over time income which accrues to investment accounts, so as to cushion against future investment losses and maintain payouts.

While IBs also face risks similar to those of CBs, some of these risks could be higher in IBs due to the specific characteristics of Islamic finance. In particular:

- $\quad$ Credit risk: The overall credit risk faced by IBs can be greater than in conventional banks given the unique characteristics of some of the financial instruments they offer. In the case of receivables (e.g., Murabahah contracts), which represent a high percentage of IBs' assets, IBs may have no option to sell at discount or to repackage and sell these financial assets as securities to take the risk off their balance sheets (these receivables have to be held until maturity). ${ }^{10}$

- Operational risk: This risk, which is the risk of losses as a result of failed internal processes, people and systems, is likely to be more relevant for IBs than for CBs (although there is no strong empirical evidence). Its importance reflects the nature of IB's financing, which is closely tied to real transactions and the special contractual features (e.g., buy and sell back). Risks include: i) improper documentation of or mistakes in the acquisition of real assets ordered by and disposed by the client; ii)

\footnotetext{
${ }^{9}$ For example, if the accepted return on investment is 7 percent and the realized return is 6 percent, then 1 percent will be paid to investment account holders from the PER account. About 58 percent of countries with IBs have allowed PER (Song and Oosthuizen, 2014).

${ }^{10}$ Credit risk management for IBs can be complicated in the case of default by the counterparty as IBs are prohibited from charging any accrued interest or imposing any penalty (except if there is deliberate delay). During this delay, the bank's capital is stuck in a nonproductive activity and the bank cannot earn any income. IBs have tried to mitigate this risk through better collateralization (Greuning and Iqbal, 2008).
} 
cancellation risk in a nonbinding Murabahah contracts; and iii) managing commodity inventories and other real assets in illiquid markets (Greuning and Iqbal, 2008).

- $\quad$ Liquidity risk: This risk is exacerbated in IBs due to several factors, including that they: i) rely on short-term retail funding; ii) tend to operate in environments with underdeveloped Shariah-compliant interbank and money markets and government securities; iii) have limited ability to hedge certain risks due to prohibitions against the use of conventional derivatives, and iv) have limited access to lender of last resort facilities. While in recent years initial steps have been taken to help develop Islamic money market instruments and Islamic lender of last resort models (Čihák and Hesse, 2008), most of the factors exacerbating liquidity risks remain present.

- $\quad$ Transparency risk: This risk, which can lead to losses due to bad decisions based on incomplete or inaccurate information (e.g., opacity of balance sheets and complex asset structures). This risk is important in IBs given the use of nonstandard conventions for reporting Islamic financial contracts and the lack of uniform standards of reporting among banks. Differences in financial reporting, auditing and accounting treatment partly reflect differences in interpretation of Shariah rules.

- $\quad$ Legal risk: The lack of consensus among Islamic scholars regarding Shariahcompliant transactions creates significant legal uncertainty. Lack of contract standardization and varying criteria on Shariah compliant contracts may add to the legal risk borne by IBs. Poor enforceability of contractual agreements increases IBs' exposure to counter-party risks of default and delinquency (El-Hawary, Grais and Iqbal, 2004).

- $\quad$ Fiduciary risk: This risk has a specific nature in the case of IBs given the PLS feature of Islamic finance. It is defined as the legal liability arising from a breach of the investment contract for mismanagement of investors' funds (for examples, see Greuning and Iqbal, 2008). This legal liability exposes the bank to the direct losses associated with the breach of its fiduciary responsibility toward unrestricted account holders and to indirect losses associated with a decline in the market price of its listed shares (El-Hawary, Grais and Iqbal, 2004).

Some features of IBs could make them more stable than CBs. In particular: i) the risk-sharing arrangements on the liability side arguably provide an additional layer of protection to the bank (on top to its book capital); ii) there are incentives for Islamic banks to be more conservative given the need to provide a stable and competitive return to investors, the shareholders' responsibility for negligence or misconduct, and the difficulty in accessing liquidity; iii) Islamic financial products are usually associated with real economic activities; iv) investment account holders have more incentives to exercise tight control over bank management since they share in the risks (and typically have no deposit insurance), and v) Islamic banks have traditionally held a larger proportion of their assets in reserve accounts 
with central banks (or in correspondent accounts with other banks) partly due to the lack of short-term investment opportunities (Hesse, Jobst and Sole, 2008).

In sum, whether IBs are more stable than $\mathrm{CBs}$ is an empirical issue. The answer depends on the relative size of the risks and may differ from country to country and from bank to bank. In this context, it has been argued that:

- $\quad$ Large IBs are weaker than large CBs, small IBs are stronger than small CBs, and small IBs are stronger than large IBs (Čihák and Hesse, 2008). ${ }^{11}$ A possible explanation of the higher stability of small IBs could be that these banks concentrate on low risk investment and fee income, whereas large banks do more PLS activities. ${ }^{12}$ In addition, it is significantly more complex for large IBs to adjust their credit risk monitoring system as profit and loss sharing activities are more difficult to standardize than loans in commercial banks. Thus, as the scale of the banking operations grows, monitoring of credit risk becomes more complex leading to greater prominence of problems related to adverse selection and moral hazard. In the case of Pakistan, however, there is evidence that credit risk exposure is less for IBs than for CBs (Baele, Farooq, and Ongena, 2012). ${ }^{13}$

- $\quad$ IBs and CBs are more alike than traditionally thought. In particular, few significant differences are found regarding their business models and, while IBs appear to be less efficient than CBs, evidence also suggests that IBs have higher loan-to deposit ratios, better asset quality and higher capitalization than CBs. These differences seem to be driven by country rather than bank type differences (though there are significant variations across Islamic banks of different sizes) (Beck, Demirgüç-Kunt and Merrouche (2013). In the case of Pakistan, for example, it has been argued that Islamic banks are less prone to withdrawals during bouts of liquidity stress and that their lending decisions might be less sensitive to changes in deposits (Zaheer and Farooq, 2014).

- $\quad I B s$ were affected differently than CBs during the 2008-09 crisis (Hasan and Dridi, 2010). In particular, factors related to the business model of IBs helped limit the

\footnotetext{
${ }^{11}$ Čihák and Hesse (2008) stressed that these results should be viewed as preliminary given caveats related to cross-country data on Islamic banks. The results are based on a comparative assessment of z-scores (a measure of financial stability) of CB and IBs in 18 countries where IBs accounted for more than 1 percent of total assets during 1993-2004. Large (small) banks are defined as having assets larger (smaller) than US\$1 billion.

${ }^{12}$ Ernst and Young World Islamic Banking Competitiveness Report (2013-2014) also shows that leading IBs are not necessarily the most profitable. The leading IBs posted 19 percent lower return on equity than comparable CBs, broadly in line with evidence that large IBs are weaker than large CBs.

${ }^{13}$ In the case of Malaysia, standalone IBs with higher capital starting positions tend to do better in solvency tests than Islamic subsidiaries of conventional banks (International Monetary Fund, 2014).
} 
adverse impact on profitability in 2008 (e.g., adherence to Shariah law prevented these banks from investing in the type of instruments that affected conventional banks and triggered the crisis), while weaknesses in risk management practices and impact of the crisis on the real economy led to a larger decline in profitability in 2009 compared to CBs (e.g., exemption from concentration limits in some countries led to high sectoral concentration, including in the United Arab Emirates where Islamic banks exceeded the 25 percent limit on lending to the real sector). Additional evidence suggests that better asset quality and higher capitalization and liquidity holdings helped IBs outperform CBs during the 2008-09 crisis (Beck, Demirgüç-Kunt and Merrouche (2013).

\section{The Legal, Corporate AND Regulatory Frameworks In ISLAMIC BANKING}

Given the risks faced by IBs, they need legal, corporate and regulatory frameworks as much as CB does. The aim of these frameworks should be to reinforce bank's operating environment, internal governance and market discipline to help address moral hazard considerations, safeguard the interest of demand depositors, and systemic risk.

\section{A. The Legal Framework}

A sound legal framework is a key precondition for a safe development of IB. In order to provide the legal foundations for the supervision of Islamic banks, general banking laws (or specific laws related to Islamic banks) need to define the nature of these banks and their operating relationship with the central bank and other conventional banks (if present). Given that IBs operate across countries in very different legal environments that reflect diverse legal traditions and divergent views on the Shariah as source of law, jurisdictions have adopted different approaches when developing the legal framework that allows the operation of IBs (Song and Oosthuizen, 2014). In particular:

- $\quad$ Shariah incorporated jurisdictions (i.e., those which incorporate in various degrees Shariah into the substantive law of the land): have aimed at developing harmonized Shariah standards for IB, although variations reflecting local standards persist. As a result, these jurisdictions have different approaches to the type of institutions that are permitted to conduct IB. For example, some jurisdictions do not allow the operation of Islamic windows (e.g., Iraq, Kuwait and Jordan) or the conversion of a CB into an IB (typically those where the Muslim population is a majority).

- $\quad$ Purely secular jurisdictions: have aimed at enacting legislative changes to ensure a level playing field for Islamic finance products, while not necessarily incorporating Shariah elements in the substantive law of the land. Examples include Singapore (e.g., amending banking and tax laws in the early 2000s), United Kingdom (e.g., allowing the establishment of Islamic banks under the 2000 Financial Services and Markets Act), France (e.g., tax changes in 2008 and amendments to the French Civil 
Code in 2009), Japan (e.g., amending the Asset Securitization Law in 2012), and Hong Kong (amending the tax law in 2013).

An important decision to be made by jurisdictions allowing IBs is whether to maintain a unified core set of banking laws or regulations for IBs and CBs. Some jurisdictions relatively new to IB seem to have preferred issuing separate laws and regulations (e.g., Lebanon, Morocco and Oman), probably to increase transparency and compensate for lack of experience, whereas some mature markets (e.g., Malaysia) have maintained the separation for development purposes. However, most jurisdictions have adopted a unified core set of banking laws and regulations covering IBs and CBs. This has the advantage of avoiding duplication of legal and regulatory provisions that are equally important for IBs and CBs (Song and Oosthuizen, 2014).

\section{B. Corporate Governance}

The nature of the IB business model gives rise to unique governance challenges, including safeguarding the interests of investment account holders and defining the role of Shariahcompliance governance. As noted earlier, the divergence of interests between holders of investment accounts and shareholders needs to be recognized in the bank's governance structure. To that effect, the 2006 guiding principles of the Islamic Financial Services Board (IFSB) on corporate governance of IBs advocated: i) transparency in policies and performance related to the investment accounts to help ensure adequate monitoring by their holders, and ii) the establishment of an internal board-level governance committee that will be empowered to oversee the governance policy framework, including protecting the interests of investment account holders. However, important gaps still need to be addressed, including: i) it is impractical for IBs to provide to investment account holders with all relevant information to alert them on the risks facing the bank, and ii) since the governance committee reports directly to the bank board, any conflict of interests between investment account holders and shareholders will likely be disclosed ex-post, if at all. In order to address this issue a potential avenue would be to mandate that one or more of the directors of the bank be accountable for enforcing the rights of investment account holders.

Shariah-compliance is a unique feature of IB and is key to help ensure the integrity of IBs. The IFSB has stressed the need for IBs to introduce a mechanism for obtaining and applying rulings from Shariah scholars and monitoring Shariah-compliance. In line with IFSB recommendations, the governance of Shariah-compliance in IBs is expected to include: i) a Shariah supervisory board (SSB), composed of qualified scholars appointed by shareholders and reporting to the board of directors, and with the responsibility of approving products and services and conducting reviews to ensure Shariah-compliance (among others); ii) an internal Shariah review process, carried out by an independent department to monitor, evaluate and produce reports on compliance; and iii) periodic Shariah reviews covering policies and transactions, which form the basis of the report of the SSB. 
A key decision to be made is whether to establish a centralized SSB (in addition to SSBs at a bank level) to oversee the Shariah governance framework in IBs. A centralized SSB has the advantage of harmonizing Shariah-rulings, reducing Shariah and compliance costs to IBs. A centralized SSB could be set up by the regulator, or IBs can be encouraged to collectively establish such a board (which is relevant in secular jurisdictions where the substantive law of the land prohibits the regulator from direct involvement in Shariah issues).

The practice in setting up a SSB varies across countries. The lack of uniformity in the application of Shariah governance standards largely reflects variations in the approach to Shariah issues across countries, constraints on the local availability of qualified scholars, ${ }^{14}$ and the state of development of the IB. In most Shariah incorporated jurisdictions, IBs are required to have a Shariah-Board and, in some cases, its work has been complemented by the establishment of a centralized SSB. In some jurisdictions (e.g., Sudan, Turkey, the United Arab Emirates) the centralized SSBs has been set up as an independent public institution, while in others (e.g., Afghanistan, Bahrain, Malaysia, Pakistan, and Palestine), the SSB has been set up at the central bank (Song and Oosthuizen, 2014).

SSBs also tend to differ in their mandate and accountability to the IBs' board of directors. While some SSBs that have been set up at the central bank have legislative and adjudicative powers on Shariah issues, other SSBs are simply consulted on proposed amendments to the regulatory framework. On accountability, a key challenge is whether SSB members are accountable to the IBs' board of directors. In most cases, it seems that the relationship of an IB's SSB with the bank is of an advisory type as the ultimate responsibility for Shariah compliance appears to lie with the bank's board of directors. While this is in line with IFSB standards on Shariah governance, transparency about the mandate, accountability and independence of the SSBs could be enhanced further to reduce reputation and legal risks associated with Shariah compliance (Song and Oosthuizen, 2014).

\section{The Regulatory Framework}

Ensuring an adequate alignment of the regulatory framework with the guidelines of standard setters is key to address the main risks inherent in IBs operations. The authorities should also ensure that the regulatory framework for Islamic banks puts them at a level playing field with CBs. In most countries where IBs are present, the conceptual regulatory framework of the Basel Committee on Banking Supervision (BCBS) is the default framework. However, several jurisdictions complement it by the standards of the Islamic Financial Services Board (IFSB) and the Accounting and Auditing Organization for Islamic Financial Institutions (AAOIFI) to give effect to Shariah Law compliance. In particular, about 65 percent of the

\footnotetext{
${ }^{14}$ While the presence of qualified scholars' in many SSB may contribute to harmonization of Shariah rulings, the issue of fit and proper procedures related to individuals that play a key role in a Shariah Board deserves a thorough assessment due to possible implications on the alignment of incentives and competition among banks.
} 
jurisdictions that allow IBs have tailored their conventional banking regulations for IB activities (Song and Oosthuizen, 2014). There are several dimensions of the regulatory framework that need to take into account the special characteristics of IB. These dimensions are discussed below.

\section{Licensing}

Several elements of an appropriate licensing process are common to IBs and CBs, but certain modifications are needed to take into account the nature of IB. In particular, in countries where Shariah law constitutes (or is part) of the fundamental law of the country, applicants for IB licenses are required to provide information on their plans for Shariah compliance. This, in turn, entails providing evidence that a robust corporate governance structure tailored to IB is in place (Section IV.B) ${ }^{15}$ However, few jurisdictions (if any) apply fit and proper requirements to SSB members and to staff in IBs in charge of Shariah compliance (Song and Oosthuizen, 2014). Developing and implementing these fit and proper requirements would be important.

\section{Liquidity}

The liquidity risks faced by IBs can generally be addressed by a combination of BCBS and IFSB liquidity rules. That said, as is the case in many emerging and developing economies, implementation of key elements of the newly internationally agreed liquidity framework (i.e., the liquidity coverage ratio (LCR), and the net stable funding ratio (NSFR) is likely to pose significant challenges to jurisdictions with strong IB presence. This is particularly the case regarding the treatment of investment accounts, the determination of run-off rates on deposits in the absence of Islamic deposit insurance schemes in many countries, and limited availability of short-term liquid instruments. ${ }^{16}$ In this context, the IFSB is expected to issue a standard on LCR for IBs in the near future. LCR implementation will demand careful planning and dedicated resources (e.g., the creation of a dedicated unit in the supervisory agency). For jurisdictions where an LCR rule does not exist and cross-border activities are minimal, the aim should be to gradually move to the LCR framework to give banks time to improve their capacity. During this transition, consideration should be given as to whether the LCR parameters are sufficiently stringent or need to be tightened as appropriate to the local context. In addition, it would be important to assess the treatment of PSIAs from a liquidity perspective.

\footnotetext{
${ }^{15}$ In the case of licensing an Islamic baking window, the CB that applies for it should ensure the effective segregation of funds in each window (conventional and Islamic), including through appropriate internal systems and reporting processes.

${ }^{16}$ For example, the LCR requires banks to hold a diversified portfolio of high quality liquid assets (HQLA), but the room of diversification is constrained in many jurisdictions, with limited access to other HQLA than sovereign debt. In an effort to address this issue the latest Basel LCR rules promote Shariah compliant instruments, such as sukuk, as HQLA.
} 
Enhancing the regulatory framework on liquidity will need to effectively tackle the availability of short term funds. Jurisdictions with stronger IB presence have made some progress, but many challenges remain. Indeed, jurisdictions have:

- $\quad$ Developed special liquidity management instruments, including commodity murabahah. This instrument has spread rapidly based on its reliance on existing financial infrastructure (i.e., international commodity markets) and is being used in about 45 percent of jurisdictions with IB presence (Song and Oosthuizen, 2014). However, its usefulness will likely be limited by transaction costs, administrative process, the non-tradability of the contract, and unresolved Shariah concerns.

- $\quad$ Developed interbank markets for IBs. Significant progress has been achieved in few countries (e.g., Malaysia, Sudan and Bahrain) including through the development of Shariah-compliant government bonds (sukuk). Interbank markets are spreading to other countries and now operate in about 45 percent of jurisdictions with IB presence. However, the development of these markets has been affected by a chronic excess of liquidity in several jurisdictions and concerns of IBs to deal with CBs out of concern of Shariah noncompliance (Song and Oosthuizen, 2014).

- $\quad$ Achieved less progress in developing liquidity facilities with the central bank, particularly those that would assist banks faced with liquidity shortages. This largely reflects the aversion of central banks (often reflected in their mandates) to engage in transactions involving real assets, which is the basis of Islamic finance. In this context, the legal and operational frameworks of central banks need to be enhanced by allowing the development and use of Islamic liquidity management instruments. This would help ensure financial stability and increase the effectiveness of monetary policy in jurisdictions with sizable IB presence.

\section{Capital}

On capital, it is also key that jurisdictions where IBs are present focus on implementing the BCBS-IFSB framework. While complying with the Basel Core Principles for Effective Bank Supervision (BCP) should be a priority for all countries, most jurisdictions would also benefit from a progressive movement towards implementing elements of Basel II and III.

Implementation planning should start by building capacity to manage the process effectively and decision on the pace of implementation would need to consider particular characteristics of banks and banking systems, as well as supervisory constraints. In general, the reforms associated to Basel II will likely be the harder and more complex to implement in terms of capital. Indeed, it is particularly challenging to accurately estimate a key feature of Basel II: the denominator of the capital adequacy ratio (CAR), i.e., risk-weighted assets. In contrast, most of these countries usually will not have greater difficulties in complying with a key feature of Basel III: the numerator of the CAR, i.e., enhanced quality of capital and introduction of capital buffers. Indeed, most emerging markets where IBs are present usually 
operate with capital buffers in excess of Basel and regulatory minimum requirements. Also, their capital structure is essentially composed of Tier I capital, particularly common equity (Tier II capital is rarely used though the IFSB standard no. 15 allowed Tier II capital instruments whose underlying assets would be convertible into shares of common equity at the point of non-viability or insolvency).

The calculation of the CAR in IB is similar to the relevant BCBS formula, but there are significant adjustments in the recognition of sources of funds and risk-weighted assets. This is because investment account holders are usually expected to absorb losses, thus providing the bank with an additional buffer to limit the impact of adverse shocks on solvency. At the same time, however, the extent of the pass through principle to investment account holders varies depending on the extent to which IBs are involved in income smoothing practices (by allowing IRR) or investment guarantees (by allowing PER). ${ }^{17}$ Accordingly, the IFSB provides two formulas to calculate the CAR: i) a standard formula, which assumes that the investment account holder bears all the credit and market risks of the assets funded by the investment account; and ii) a discretionary formula, where an alpha factor is applied to capture the extent to which investment account holders share the losses (Annex 4).

There is a wide array of approaches to the application of capital requirements across jurisdictions. In some jurisdictions (e.g., Ethiopia, Kazakhstan, United Arab Emirates, and the United Kingdom) the BCBS capital framework applies to all banks (i.e., there is no distinction between the capital requirements that apply to IBs and CBs), while in others (e.g., Bahrain, Jordan, Malaysia and Sudan) the BCBS capital framework is complemented by the pronouncements of the IFSB to cater for IB. In addition, in those jurisdictions that calculate the CAR using the discretionary formula provided by the IFSB, there is wide variation in the value of the alpha factor chosen by the supervisor (e.g., Malaysia requires 100 percent of general assets financed by investment accounts to be converted into risk weighted assets, Sudan requires 50 percent and Bahrain and Jordan 30 percent (Song and Oosthuizen, 2014). ${ }^{18}$

This wide array of approaches to the application of capital requirements poses challenges when comparing CARs among IBs in different countries. ${ }^{19}$ To facilitate cross country comparisons and better understand banks' capital levels, supervisory authorities are encouraged to adopt IFSB standards. Accordingly, in line with IFSB guidelines, when determining the value of alpha supervisors need to assess the risk profiles of IBs, develop

\footnotetext{
${ }^{17}$ While PER is not considered part of the capital of an IB, it generally has counter-cyclical effects on the returns earned by IAHs.

${ }^{18}$ While the supervisors in Turkey do not choose a value for the alpha, in practice they apply a 70 percent risk weight to Islamic banking risk-sharing products.

${ }^{19}$ The leverage ratio for Islamic banks would take into consideration the Alpha factor according to IFSB standard 15 on revised capital adequacy. Therefore, this ratio would not be also useful for cross-country comparison purposes.
} 
robust models, decide whether to adopt it for each individual bank or for the entire system in their jurisdiction, and publish adequate disclosures on their approach of determining alpha.

\section{Transparency and disclosure}

Improving disclosure is key to provide the supervisory authorities and the public with a better understanding of banks' strategies and relevant risks. Disclosure requirements should aim at providing sufficient information to assess: i) the appropriateness of policies regarding portfolio diversification and investment objectives (including with respect to concentration); ii) the degree of exposure to illiquid assets, which could be the case particularly in banks operating under a two-tier Mudharabah arrangement; iii) the main risk factors associated with the investment portfolio and the quality of the internal procedures, organization and infrastructure for monitoring and handling these risks; iv) the adequacy of arrangements for internal controls, which is a complex issue given the need to determine PLS ratios on projects financed by the bank; and v) the methodology used by the bank to calculate its performance to help investors choose well managed institutions when placing their investment deposits. In this context, IBs disclosure of its smoothing policies (e.g., appropriations made to PER and IRR, the level of these reserves and the amount that was used for income smoothing over the period) would help reduce uncertainty regarding the loss absorbency nature of investment accounts and mitigate potential systemic risks.

Despite the importance of a transparent accounting and financial reporting framework tailored to IB, its formal incorporation into legal and regulatory frameworks has been progressing at a slow pace. Indeed, the AAOIFI accounting standards are mandatory only in a few countries (Bahrain, Botswana, Iraq, Jordan, Qatar, Sudan, Syria, and Yemen), with most jurisdictions applying International Financial Reporting Standards (IFRS) or national accounting standards. The nature and extent of information disclosed to the general public varies across jurisdictions, partly depending on whether Shariah law is the fundamental law of the land and the coexistence of IBs and CBs (Song and Oosthuizen, 2014).

\section{Deposit insurance and bank resolution}

Effectively dealing with the issue of deposit insurance is key to promote the stability of IBs. In the case of IB, the main challenge for deposit insurance is to identify its scope, including whether it covers profit sharing investment accounts (IFSB, 2013). Toward this end, the existence of a sound approach to determine the value of the alpha factor would be instrumental in determining the level of coverage needed for investment account holders. In practice, the protection of deposits in Islamic banks has little uniformity among jurisdictions. Deposit protection schemes range from single schemes applied to all banks to separate schemes where Islamic and conventional banks are covered separately. Where there is a separate deposit protection scheme for Islamic depositors (investors), such a scheme typically invests its funds from ex ante contributions only in Shariah compliant investments (Song and Oosthuizen, 2014). 
Comprehensively addressing bank resolution in the context of IB is also important. While international principles for good bank resolution are applicable to IB, regulatory work needs to be developed further, including clarifying whether there should be a separate resolution framework for IBs, the priority of claims by investment account holders, and the nature of the resolution process, particularly if it involves a takeover by a CB. Few countries have comprehensively addressed these issues (Song and Oosthuizen, 2014).

\section{The Supervision OF ISLAMic BANKING IN PraCtiCE ${ }^{20}$}

As is the case in conventional banking, prudential supervision in an IB framework is key to ensure safety and soundness of individual IBs and help reduce risks to the stability of the financial system. The conduct of banking supervision needs to be undertaken in a manner that addresses the special characteristics of Islamic banks. Thus, supervisors need to understand the challenges inherent in IB and the potential implications of the interactions between IBs and CBs, including the potential for regulatory arbitrage.

There are two models of supervision of IBs in jurisdictions where Islamic and conventional banks are present. In the first model, IBs and CBs are subject to the supervision of a single supervisory authority (e.g., Saudi Arabia, Ethiopia, Kazakhstan, Kenya, Kuwait, Qatar, Tunisia, Turkey, the United Arab Emirates, and the United Kingdom). In the second model, supervision rests with separate supervisory units within a single supervisory authority (e.g., Bahrain, Indonesia, Jordan, Lebanon, Pakistan, and Syria). In the first model a single supervisory framework applies to all banks (IBs and CBs), while in the second model, separate supervisory frameworks may be applied to IBs by the separate supervisory units. In practice there is typically substantial correspondence between the different supervisory frameworks.

The appropriateness of a particular model of banking supervision depends on country needs and circumstances. While the benefits of integration have been recognized (Čihák and Podpiera, 2007), authorities need to be aware of the costs associated with any reorganization of a regulatory and supervisory structure and consider whether to implement less costly alternatives such as enhancing communication, coordination and information sharing across agencies. In general, rather than focusing on the appropriate structure of supervision, authorities should aim at finding the most appropriate means to achieve the desired outcomes. Toward this end, an effective financial supervision needs to ensure operational independence of the supervisory agency, which has to be supported by adequate resources (e.g., the right funding, right skills, and right people), a sound legal framework, a well designed governance structure, and robust accountability practices (Viñals, et. al. 2010).

\footnotetext{
${ }^{20}$ This section is largely based on Song and Oosthuizen (2014).
} 
Although some supervisory authorities apply risk-based supervision to IBs, full Shariah compliance is still required. At a general level, supervisory authorities apply a generic supervisory framework and procedures to Islamic banks and conventional banks. Using a Capital-Asset-Management-Earnings-Liquidity-Sensitivity (CAMELS) rating system is generally appropriate, but it needs to be adapted to the risks associated with IB, particularly regarding Shariah compliance, capital adequacy, asset quality, and liquidity. Stress testing frameworks also need to be adapted. Toward this end, appropriate accounting enhancements and data collection needs to be enhanced, including by focusing on the main characteristics of IBs. At an idiosyncratic level, supervisors apply a compliance approach in relation to Islamic banking and Shariah compliance. Typically, the higher the penetration of Islam in a society, the more intense is compliance with Shariah law monitored by supervisory authorities. In jurisdictions where Islamic windows operate, strict controls and enhanced supervisory oversight is advisable to reduce the risks associated with Shariah compliance and provide adequate consumer protection.

Supervisory authorities should help ensure that IBs adopt enhanced transparency and disclosure requirements. In line with IFSB guidance, they should develop appropriate guidelines to promote good business practices, protect stakeholders, and be able to take enforcement measures in case of noncompliance. In practice, jurisdictions have adopted different approaches to the nature and extent of information which banks are required to submit to the supervisory authorities. In jurisdictions where Shariah law is not recognized and where IBs and CBs are present, all banks are subject to the same reporting requirements (this applies also to information that forms the basis for offsite supervision). In Shariah law jurisdictions where both types of banks are present, IBs may be required to submit additional information on Islamic banking transactions and products to help assess the bank's compliance with Shariah law.

Jurisdictions also have different approaches to onsite supervision. In non Shariah jurisdictions, all banks are subject to the same on-site supervision framework, there is greater focus on operational risks and supervisors take into account whether there is a discrepancy in an Islamic bank between the facts on the ground and public representations related to Shariah compliance. If the supervisory authority finds a discrepancy, it would consider its implications in relation to misselling, consumer protection, governance and internal controls (and could influence the assessment on the bank's "systems and controls" and reputational risk management). In Shariah law jurisdictions, where only IBs are permitted, up to 80 percent of the resources reportedly are devoted by the supervisory authority to ensuring Shariah compliance (and onsite examiners are well trained and well versed in Shariah law).

Developing financial soundness indicators (FSIs) for IBs, strengthening supervisory capacity on issues related to IB, and ensuring a greater focus on cross-border and consolidated supervision is also important. The development of FSIs needs to take into account the characteristics of IB and ensure adequate disclosure. This would help stakeholders understand the methodology used in calculating the FSIs, their differences with FSIs of CBs, 
and appreciate how the FSIs were taken into account when undertaking risk assessments of banks. Supervisory authorities in jurisdictions where IBs are located are encouraged to build expertise in the additional requirements needed to supervise IBs, including through technical assistance from the IFSB and other providers of technical assistance. Finally, authorities are encouraged to adopt the upcoming IFSB core principles for IB which would help reduce regulatory arbitrage across jurisdictions (among others). These core principles are aligned with the Basel Core Principles for Effective Bank Supervision and its adoption would benefit all jurisdictions where IBs are supervised on their own or together with CBs.

\section{Conclusions and Main Policy Recommendations}

While IBs and CBs have important similarities, there are also differences which largely reflect that IBs need to comply with Shariah Law. Accordingly, there are differences in the nature of risks faced by IBs and CBs. Risks that are unique to IBs arise directly from the specific characteristics of Islamic contracts (including the nature of risk-sharing). IBs also face risks similar to those of $\mathrm{CBs}$, though their relevance varies due to the specific characteristics of Islamic finance. In theory, operational, liquidity, transparency, and legal risks are greater in IBs than in $\mathrm{CBs}$ - and it could be argued that overall credit and concentration risks can also be greater in IBs.

Whether IBs are riskier than CBs is an empirical issue and the answer may differ from country to country and from bank to bank. In this context, the limited empirical evidence is somewhat inconclusive. Regarding the risks faced by IBs, the evidence does not always validate the theory. In the case of Pakistan, for example, empirical results suggest that credit risk exposure of IBs is less than in CBs and that IBs are less prone to withdrawals during bouts of liquidity stress. On the business models of IBs and CBs, some findings suggest that they are more alike than traditionally thought, but there is also evidence indicating that the business model of IBs helped limit the adverse effect on profitability in 2008 following the global financial crisis. At the same time, there are results that indicate that the better performance of IBs during the 2008-09 crisis could be explained by better asset quality and higher capitalization and liquidity holdings of IBs. Finally, results from an empirical study indicate that the riskiness of IBs may vary depending on the size of the bank.

Given the risks faced by IBs, they need a legal, corporate, and regulatory framework as much as CB does. A sound legal framework is a key precondition for a safe development of IB. While authorities have adopted different approaches when developing the legal framework, an important decision to be made is whether to maintain a unified set of banking laws and regulations when IBs and CBs operate in a particular jurisdiction. In this context, a unified set of banking laws and regulations covering IBs and CBs is advisable to avoid duplication of legal and regulatory provisions that are equally important for both types of banks. This practice has been adopted in most jurisdictions. 
The nature of the IB business model gives rise to unique governance challenges. First, divergence of interest between holders of investment accounts and shareholders needs to be recognized in the banks' governance structure. The 2006 IFSB principles are an important step in that direction. These principles established an internal governance committee to protect the interest of stakeholders other than shareholders (among others). However, some gaps still need to be addressed. For example, because the governance committee reports directly to the bank board, any conflict of interests is likely to be disclosed ex-post, if at all. In order to address this issue one or more directors of the bank could be mandated to be accountable for enforcing the rights of investment account holders.

A second governance challenge for IBs relates to Shariah compliance. In line with IFSB recommendations, a sound Shariah compliance framework is expected to include a Shariah supervisory board (SSB), an internal Shariah review process, and periodic Shariah reviews. While the practice of setting SSB varies across countries, a centralized SSB (in addition to individual SSBs at the level of IBs) has the advantage of harmonizing Shariah rulings and reducing Shariah compliance costs to IBs. In general, there seems to be a need to enhance transparency regarding the mandate and accountability of SSB to help reduce reputation and legal risks associated with Shariah-compliance.

Ensuring an adequate alignment of the regulatory framework with the guidelines of standard setters is key to address the main risks inherent in IBs operations and help achieve a level playing field with CBs. While complying with the Basel Core Principles for Effective Bank Supervision should be a priority for all countries, most jurisdictions would also benefit from a progressive movement towards implementing Basel II and III. It is expected that jurisdictions with strong IB presence will face significant challenges when implementing the LCR due to the lack of a diversified portfolio of HQLA. Furthermore, in terms of capital, the reforms associated with Basel II will likely be harder and more complex to implement due to the difficulties/different methodologies in estimating risk weighted assets. As a result, implementation of key elements of Basel II and III will demand careful planning, dedicated resources, and will need to consider particular characteristics of banks and banking systems, as well as supervisory constraints.

Enhancing the regulatory framework for IBs would be important in several dimensions. On licensing, it would be useful to develop fit and proper criteria to SSB members and to staff in IBs in charge of Shariah compliance. On liquidity, it would be particularly important to enhance the legal and operational frameworks of central banks by allowing the development and use of Islamic liquidity management instruments. On capital requirements, adoption of IFSB standards (including on estimating the factor alpha - applied to capture the extent to which investment account holders share the losses) would help facilitate cross country comparisons of CARs and better understand banks' capital levels. On transparency, adoption of AAOIFI and IFSB standards would help reduce IBs transparency risks. On disclosure, banks could be encouraged to disclose their smoothing policies to help reduce uncertainty regarding the loss absorbency nature of investment accounts. On deposit insurance, 
development of a sound approach to estimate the value of alpha would be instrumental in determining the level of coverage needed for investment account holders. Finally, on bank resolution, further developments could clarify whether there should be a separate resolution framework for IBs, the priority of claims by investment account holders, and the nature of the resolution process, particularly if it involves a takeover by a CB.

While there are generally two models of supervision of IBs (e.g., single and separate supervisory units), the appropriateness of a particular model depends on country needs and circumstances. In general, rather than focusing on the appropriate structure of supervision, authorities should aim at ensuring operational independence of the supervisory agency, which has to be supported by adequate resources, a sound legal framework, a well designed governance structure, and robust accountability practices.

Strengthening supervision of IBs requires efforts in several fronts. Supervisors are encouraged to: i) continue adapting the CAMELS rating system to the risks associated with IBs, particularly regarding capital adequacy, asset quality, management and liquidity; ii) employ stress testing techniques that take into consideration the risk specificities of IBs; iii) apply strict controls and enhance supervisory oversight in jurisdictions where Islamic windows operate to help reduce risks associated with Shariah compliance and provide adequate consumer protection; iv) help ensure adopting enhanced transparency and disclosure requirements, including by developing FSI for IBs; v) strengthen supervisory capacity on issues related to IBs, and vi) increase their focus on cross-border and consolidated supervision.

IB is likely to continue growing in the years ahead. IB could potentially have a key role to play in gearing finance (in the countries they operate) towards a social common goal tied to supporting the real economy and possibly reducing incentives to financial engineering associated with complex instruments. While IB may currently be in a developmental mode reflecting the need for further legal, accounting, governance, regulatory and supervisory enhancements, its role is likely to increase over time in promoting financial inclusion. 


\section{Annex 1. Shariah Law and Islamic Banking ${ }^{1}$}

The basic framework for an Islamic financial system is a set of rules and laws, collectively referred as Shariah. Shariah governs economic, social, political and cultural aspects of Islamic societies and originates from the rules dictated in the Qur'an. Further elaboration of these rules is provided by scholars in Islamic jurisprudence. Whereas in several jurisdictions, Shariah law is the fundamental law of the land (or a key source of the law of the land) in others it does not constitute part of the legal framework.

IB has certain specific requirements and characteristics. The basic principles of IB include: i) the prohibition of riba (e.g., interest), which is the central tenet of the system and is based on arguments of social justice, equality and property rights; ii) risk sharing, where the suppliers of funds become investors instead of creditors and providers of financial capital and entrepreneurs share business risks in return for a share of profits; iii) prohibition of speculative behavior, which discourages hoarding and prohibits transactions featuring extreme uncertainty and gambling; iv) sanctity of contracts, which intends to reduce asymmetric information and moral hazard; v) Shariah-approved activities, which prohibits (among others) any investment in business dealing with drugs, alcohol, pork, and games of chance (banks' involvement in trading in financial risk is seen as a form of gambling); and (vi) social justice, whereby any transaction leading to injustice and exploitation is prohibited.

There are various motivations underlying the place and role of IB within different jurisdictions. In some jurisdictions, IB is considered to be an acceptable financial innovation whose presence further promotes that jurisdiction's standing as an international financial center. Other jurisdictions accommodate IB in view of the adherence of a substantial minority of its population to Islam and the demand for IB from the Muslim community. In jurisdictions its presence accommodates the needs of a Muslim majority, where Shariah law is the fundamental law, and where Islam is the state religion.

\footnotetext{
${ }^{1}$ This annex is based on Song and Oosthuizen (2014) and Van Greuning and Iqbal (2008).
} 


\section{Annex 2. Definition of Key Shariah-compliant Contracts ${ }^{1}$}

\section{Sources of Funds (Deposits)}

Profit Sharing Investment Account (PSIA) is a contract by which an investor/depositor opens an investment fund with an Islamic bank (IB) on the basis of Mudharabah. The IB could have restricted or full discretionary power in making investment decisions. The IB acts as an entrepreneur while the PSIA holder acts as a capital provider. Both parties agree on a ratio of profit sharing, which must be disclosed and agreed upon at the time of opening the account. Profits generated by the IB are shared with the PSIA holder in accordance with the terms of the Mudharabah agreement while losses are borne solely by the PSIA holder, unless they are due to IB's misconduct, negligence or breach of the contract terms. Usually the IB's money (bank capital) is invested in the same income-producing assets or economic activities. Hence, low income (losses) affect the IB through low (negative) return on shareholders' invested capital and low (zero) income from managing PSIA accounts. This source of revenue is the main one for the IB, and it is used to cover operational expenses.

A Wadiah (deposit) is a contract between the depositor and the IB (custodian) for safekeeping. The depositor grants the IB permission to utilize the funds for whatever purpose permitted by Shariah. The bank in return guarantees the value of the deposit and allows the depositor easy access for withdrawals whenever needed.

\section{Uses of Funds (Financing and Investment)}

A Murabahah (Cost-plus financing) contract refers to an agreement whereby the IB sells to a customer, at acquisition cost plus an agreed profit margin, a specified kind of asset that is already in its possession (such as a manufactured good). Following delivery of the asset, a credit risk in respect of the amount receivable from the customer arises. From the perspective of modern finance, a Murabahah facility is similar to an asset-backed risky loan.

A Salam (Purchase with deferred delivery) contract refers to an agreement to purchase, at a predetermined price, a specified kind of commodity (physical product) which is to be delivered on a specified future date in a specified quantity and quality (such as an agricultural or a manufactured product). As the buyer, the IB makes full payment of the purchase price upon execution of the Salam contract. To mitigate price risk, in certain cases, the IB enters into a back-to-back contract, namely Parallel Salam, to sell a commodity with the same specification as the purchased commodity under a Salam contract to a party other than the original seller.

\footnotetext{
${ }^{1}$ This annex is based on Hasan, M. and J. Dridi (2010).
} 
An Ijarah (Lease) contract refers to an agreement whereby the IB leases to a customer an asset (such as a ship, aircraft, or telecom equipment) for an agreed period against specified installments of lease rental. The contract commences with an agreement to lease that is binding on the part of the potential lessee and requires the IB to purchase or lease an asset prior to entering into the contract. An Ijarah contract could offer the lessee the option to purchase the asset either at the end of the lease period by means of a gift or a token consideration, or by installments of a specified amount during the lease period.

A Musharakah (Equity financing) contract is an agreement whereby the IB and a customer contribute capital to an enterprise, whether existing or new, or to the ownership of real estate or a moveable asset, either on a permanent basis or on a diminishing basis where the customer progressively buys out the share of the IB ("diminishing Musharakah"). Profits generated by the enterprise or the asset/real estate are shared in accordance with the terms of the Musharakah agreement, while losses are shared in proportion to the respective contribution to capital.

A Mudharabah (Participation or trust financing). It is a contract that refers to an agreement whereby the IB contributes capital to an enterprise or activity which is to be managed by the customer/investor. Profits generated by that enterprise or activity are shared in accordance with the terms of the Mudharabah agreement, while losses are to be borne solely by the IB unless they are due to the customer/investor's misconduct, negligence, or breach of the contract terms. 


\section{Annex 3. Islamic Window vs. Fully-fledged Islamic Bank ${ }^{1}$}

According to supervisory authorities who allow windows consider that this structure has the following advantages:

- IB services/products benefit from the experience of conventional banks. This might improve the quality of services/products and lower their cost, which could enhance intermediation. Windows also facilitate liquidity management, especially in countries where Islamic liquidity instruments are limited. Windows usually have easy access to liquidity support from the conventional part of the bank.

- Windows enhance competition in the market, which could lower the cost of finance for Shariah-compliant products.

- $\quad$ For countries with small demand for Islamic banking services, opening an Islamic window could be the only feasible way of providing IB services, thus enhancing financial inclusion.

Supervisory authorities who do not allow windows consider that this structure has the following risks:

- The commingling of Islamic windows with conventional assets and liabilities could have significant reputational risk, as depositors in windows might suddenly withdraw their money if rumors regarding commingling arise. It also raises issues related to consumer protection and segregation of funds.

- $\quad$ The windows could hinder the establishment of effective corporate governance and risk management systems. The management and board of a conventional bank may not be sufficiently attuned to the unique risks inherent in Islamic banking activities. Fit and proper criteria in conventional banks operating windows are unlikely to be met in the Islamic banking part of the bank. Shariah Boards might be unable to verify the complete segregation of assets and liabilities.

- The operation of windows could lead to regulatory arbitrage or unfair practices. For example, given the profit-and-loss sharing nature of windows' accounts, risky financing could be encouraged to get Islamic financing through windows because, in the case of default, the account holders of windows will bear the losses.

\footnotetext{
${ }^{1}$ This annex is based on Song and Oosthuizen (2014).
} 
- Windows could hinder effective financial oversight. Some prudential ratios that might differ for Islamic banking could be difficult to monitor appropriately. Windows could also hinder the preparation of proper financial statements.

- $\quad$ The issue of how distressed Islamic banks should be resolved in accordance with Shariah principles is still under deliberation. This issue is further complicated for an Islamic window operating within a conventional bank. An orderly resolution of a distressed conventional bank (with an Islamic window) may not satisfy financial stability objectives and Shariah principles.

- $\quad$ Monitoring the impact of using an Islamic monetary instrument (e.g., Sukuk) could be difficult. The pricing of Islamic banking activities will not be strongly linked to a Shariah-compliant liquidity level since conventional banks can use conventional deposits to finance Islamic banking assets, potentially hindering the design of appropriate monetary policies. 


\section{Annex 4. Capital Adequacy in Islamic Banking ${ }^{1}$}

While computation of the required capital adequacy ratio in IB is similar to the relevant BCBS formula, there are variations in the recognition of sources of funds and risk-weighted assets. As noted in the Section II of this note, an important difference between IBs and CBs is related to the profit sharing investment account (PSIA). Unlike depositors of conventional banks, PSIA holders are neither depositors nor equity holders. They are quasi-liability holders and are expected to absorb all losses on the investments made with their funds, unless there is evidence of negligence or misconduct on the part of the bank. Given the capacity to pass-through low returns or losses to PSIA holders, this provides IBs with an additional buffer to limit the impact of adverse shocks on solvency. The higher the share of PSIA as a source of funds and the lower their sensitivity to changes in returns, the better the solvency of IBs compared to CBs.

The assignment of risk weights to different classes of assets is also different in IBs. This is because in Islamic banks the assets range from trade financing to equity partnership, which may cause the calculation of risk weights to be different from conventional banks. In addition, the presence of income smoothing practices has indirect implications for IBs'capital adequacy (e.g., in some countries, IBs maintain reserves for income smoothing purposes) and regulators may take this into account when determining the capital adequacy ratio.

In December 2006, a working group of the IFSB issued the first capital adequacy standard to cater for institutions (other than insurance institutions) offering Islamic financial services. Minimum capital adequacy requirements for credit and market risks are prescribed for each Shariah-compliant financing and investment instrument. As in conventional institutions, in the IFSB standard the minimum regulatory capital adequacy requirement for IBs is 8 percent. In May 2008, IFSB issued the guidance note on the recognition of ratings by external credit assessment institutions to facilitate the application of Basel II. The IFSB also revised its capital adequacy standards in December 2013 to incorporate many elements of Basel III.

For the calculation of the capital adequacy ratio, the IFSB standard provides two forms: standard and discretionary. In the standard formula, capital is divided by risk-weighted assets excluding the assets financed by investment account holders. The discretion formula is modified to accommodate reserves maintained by Islamic banks to minimize displaced commercial, withdrawal, and systemic risks. In markets where Islamic banks maintain profit equalization reserves (PER) and investment risk reserves (IRR), the supervisory authorities have discretion to adjust the denominator of the CAR formula. ${ }^{2}$ The IFSB Supervisory Discretionary Formula for CAR can be expressed as:

\footnotetext{
${ }^{1}$ This annex is based on Song and Oosthuizen (2014).

${ }^{2}$ Van Greuning and Iqbal (2008).
} 
[Eligible Capital]/\{[total risk-weighted assets +operational risk]-[RWAs funded by restricted profit sharing investment accounts (credit + market risk) $-\left[\left(1-\alpha^{*}\right)\right.$ total risk-weighted assets funded by unrestricted profit-sharing investment accounts] $-[\alpha *$ risk-weighted assets funded by PER and IRR of unrestricted profit sharing investment accounts]?

where $\alpha^{*}(\mathrm{alpha})$ is the proportion of assets funded by unrestricted profit sharing investment accounts and is determined by the supervisory authorities. ${ }^{3}$ An unrestricted profit sharing account (URIA) allows the fund manager (the bank) to invest in activities in any sector, industry or project they found suitable. The bank can commingle these funds with their own funds and invest them in a pooled portfolio. The Restricted Investment Account (RIA) restricts the fund manager (the bank) to invest in activities, sectors or projects selected by the investor. In practice, URIAs are more common.

There is a wide variety of practices regarding the adjustment of the denominator of the CAR formula. While some Islamic banks are required to hold capital against assets financed by an URIA, in others banks are required to hold capital against assets financed by a RIA. Furthermore, in some cases the PER was considered eligible capital for the regulatory CAR, whereas in others an IRR was considered eligible capital for such purposes. ${ }^{4}$

\footnotetext{
${ }^{3}$ IFSB issued in March 2011, a guidance note with a methodology to estimate the value of alpha to be used in the supervisory discretion formula.

${ }^{4}$ IFSB-15 (Revised capital adequacy standards for institutions offering Islamic financial services) made it clear that PER and IRR are not part of the capital of Islamic banks.
} 


\section{REFERENCES}

Baele, Lieven, Farooq, Moazzam, and Steven Ongena, 2012, “Of Religion and Redemption: Evidence from Default on Islamic Loans," European Banking Center Discussion paper, No. 2012-008 and CentER Discussion Paper, No. 2012-014.

Beck, Thorsten, Demirgüç-Kunt, Asli, and Ouarda Merrouche, 2013, "Islamic vs. conventional banking: Business model, efficiency and stability," Journal of Banking and Finance No. 37, pp. 433-47.

Chong, Beng Soon and Ming-Hua Liu, 2009, "Islamic banking: Interest-free or interestbased?” Pacific-basin Finance Journal No. 17, pp. 125-44.

Čihák, Martin and Heiko Hesse, 2008,"Islamic Banks and Financial Stability: An Empirical Analysis," IMF Working Paper 08/16 (Washington: International Monetary Fund).

Čihák, Martin and Richard Podpiera, 2007, "Is one Watchdog better than three? International Experience with Integrated Financial Sector Supervision,” IMF Working Paper 06/57 (Washington: International Monetary Fund).

El-Hawary, Dahlia, Wafik Grais, and Zamir Iqbal, 2004, "Regulating Islamic Financial Institutions: The Nature of the Regulated," World Bank Working Paper No. 3227 (Washington: The World Bank).

Ernst and Young, 2013-2014, World Islamic Banking Competitiveness Report.

Errico, Luca and Mitra Farahbaksh, 1998, "Islamic Banking: Issues in prudential Supervision and Regulation,” IMF Working Paper 98/30 (Washington: International Monetary Fund).

Van Greuning, Hennie and Zamir Iqbal, 2008, "Risk Analysis for Islamic Banks," (Washington: The World Bank).

Hasan, Maher and Jamma Dridi, 2011, "The Effects of the Global Crisis on Islamic and Conventional Banks: A Comparative Study," IMF Working paper 10/201 (Washington: International Monetary Fund).

Hesse, Heiko, Andreas A. Jobst and Juan Sole, 2008, “Trends and Challenges in Islamic Finance", World Economics vol. 9, no. 2, pp. 175-93.

International Monetary Fund, 2014, "Malaysia: Financial Sector Assessment Program," Stress Testing the Malaysian and Labuan IBFC Banking Sectors Technical Note.

Islamic Financial Services Board, 2013, "Financial Stability Report." 
Jobst, Andreas, 2007, "The Economics of Islamic Finance and Securitization," IMF Working paper 07/117 (Washington: International Monetary Fund).

Khan, Feisal, 2010, "How "Islamic" is Islamic Banking," Journal of Economic Behavior and Organization No.76, pp. 805-20.

Sole, Juan, 2007, "Introducing Islamic Banks into Conventional Banking Systems," IMF Working Paper 07/175 (Washington: International Monetary Fund).

Song, Inwon and Carel Oosthuizen, 2014, "Islamic Banking Regulation and SupervisionSurvey Results and Challenges," IMF Working paper No. 14/220, (Washington: International Monetary Fund).

Viñals, José, Jonathan Fiechter, Aditya Narain, Jennifer Elliot, Ian Tower, Pierluigi Bologna, and Michael Hsu, 2010, "The Making of Good Supervision: Learning to Say No," IMF Staff Position Note 10/08 (Washington: International Monetary Fund).

Zaheer, Sajjad and Moazzam Farooq, 2014, "Liquidity Crisis: Are Islamic Banking Institutions more Resilient?," paper presented at the IMF conference on "Macroeconomic Challenges Facing Low-Income Countries," Washington, DC, January 30-31, 2014. 